\title{
On the Rand: Determinants of the South African Exchange Rate
}

\author{
Jeffrey Frankel \\ CID Working Paper No. 139 \\ March 2007
}

(C) Copyright 2007 Jeffrey Frankel and the President and Fellows of Harvard College

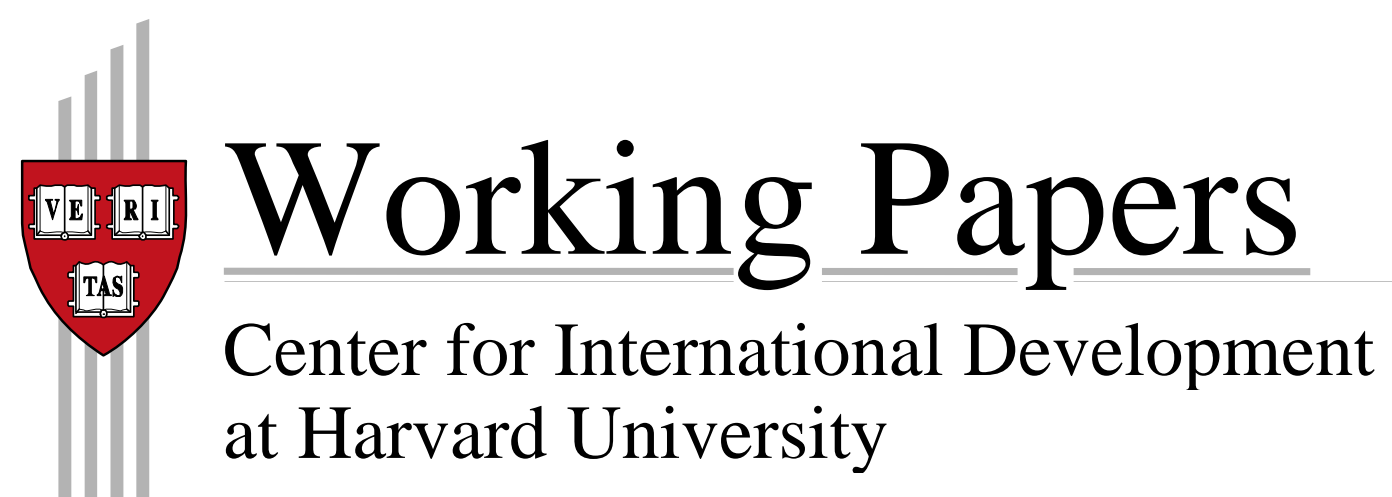




\title{
On the Rand: Determinants of the South African Exchange Rate Jeffrey Frankel \\ Kennedy School of Government and Center for International Development, Harvard University
}

DRAFT: Previous version, August 2006, This version, March 2007

\begin{abstract}
This paper is an econometric investigation of the determinants of the real value of the South African rand over the period 1984-2006. The results show a relatively good fit. As always with exchange rate equations, there is substantial weight on the lagged exchange rate, which can be attributed to a momentum component.

Nevertheless, economic fundamentals are significant and important. This is especially true of an index of the real prices of South African mineral commodities, which even drives out real income as a significant determinant. An implication is that the 2003-2006 real appreciation of the rand can be attributed to the Dutch Disease. In other respects, the rand behaves like currencies of industrialized countries with well-developed financial markets. In particular, high South African interest rates raise international demand for the rand and lead to real appreciation, once one also controls for a forward-looking measure of expected inflation and a measure of default risk or country risk. It is in the latter respects, in particular, that the paper purports to improve on earlier studies of the rand.
\end{abstract}

Keywords: South Africa, rand, commodity currency, Dutch Disease, mineral prices, country risk

\section{JEL Codes: F31}

This work was done with the able research assistance of Melesse Tashu. It is a contribution within the Macroeconomics Group of the Harvard University Center for International Development's Project on South Africa: Performance and Prospects. Relative to an earlier draft in mid-2006, the major innovations in this paper include: the addition of an absent theoretical model, the use of sovereign spread data to measure the risk premium and forward-looking inflation forecasts to measure real interest rates, allowing a break in 1995 for the end of apartheid and capital controls, and a dynamic simulation of the real value of the rand over 2003-2006. Thanks to Lesetja Kganyago, Ben Smit and other participants in the July 2006 meetings in Pretoria and to Brian Kahn, Stan du Plessis and other participants in the January 2007 meetings in Pretoria and Stellenbosch. None are implicated in the conclusions.

This paper is part of the CID South Africa Growth Initiative. This project is an initiative of the National Treasury of the Republic of South Africa within the government's Accelerated and Shared Growth Initiative (ASGI-SA), which seeks to consolidate the gains of post-transition economic stability and accelerate growth in order to create employment and improve the livelihoods of all South Africans. 
The rand has undergone large movements in recent years. What explains these swings? Important questions include:

- Is the rand a commodity currency, like the Australian and Canadian dollar are said to be (to pick two floaters)? That is, is it a currency that appreciates when prices of the mineral products that it produces are strong on world markets and depreciates when they are weak?

- In other respects, does the rand behave like currencies of industrialized countries, in light of its developed financial markets? (South Africa borrows in rand, for example, unlike most developing countries.) This does not necessarily mean fitting standard theories closely, as those theories don't work well in practice for major industrialized currencies either. But such variables as GDP and rates of return should have an effect.

- Did the removal of capital controls in 1995, or other elements of the transition to democracy, cause a structural break in the determinants of the real exchange rate?

- Has there been an element of momentum to some recent movements, or can they be explained by fundamentals?

Figure 1 suggests that there has been a relationship between the real mineral price and real exchange rate: the currency slumps when mineral exports are declining, as in the late 1990s, but appreciates in natural resource booms as in 2002-2006 -- the classic Dutch Disease. But figure 2 shows that the real exchange rate has the same correlation with relative real output, which could be explained either as a reflection of the BalassaSamuelson effect (wherein productivity growth increases the price of nontraded goods relative to traded goods) or as a reflection of monetary theories of the nominal exchange rate (wherein growth in real income raises the demand for money and appreciates the currency nominally). We may have some trouble distinguishing the effect of mineral prices from the effect of real output, because the two are themselves highly correlated, as Figure 3 shows. 


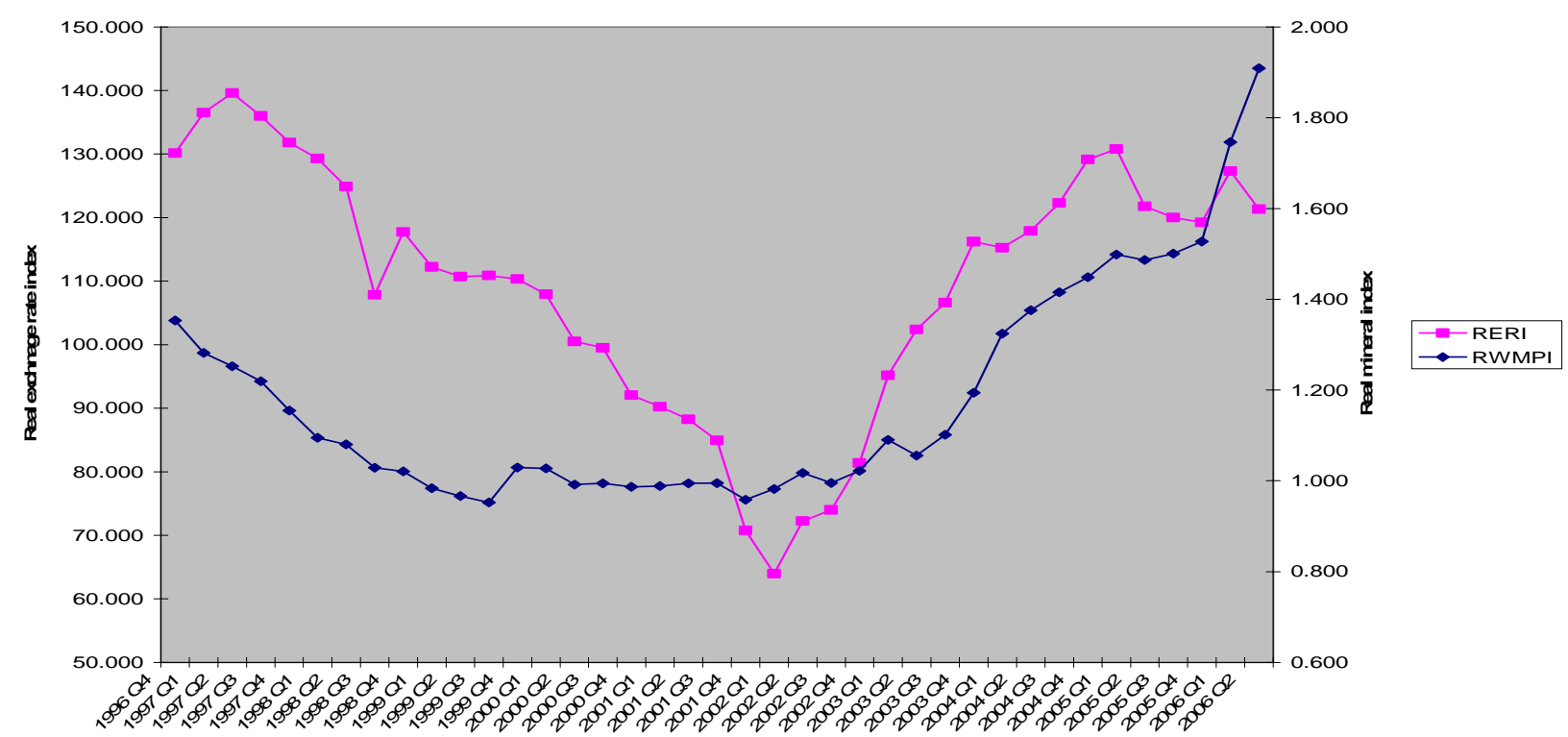

Figure 1: Real Exchange rate index and real mineral price index

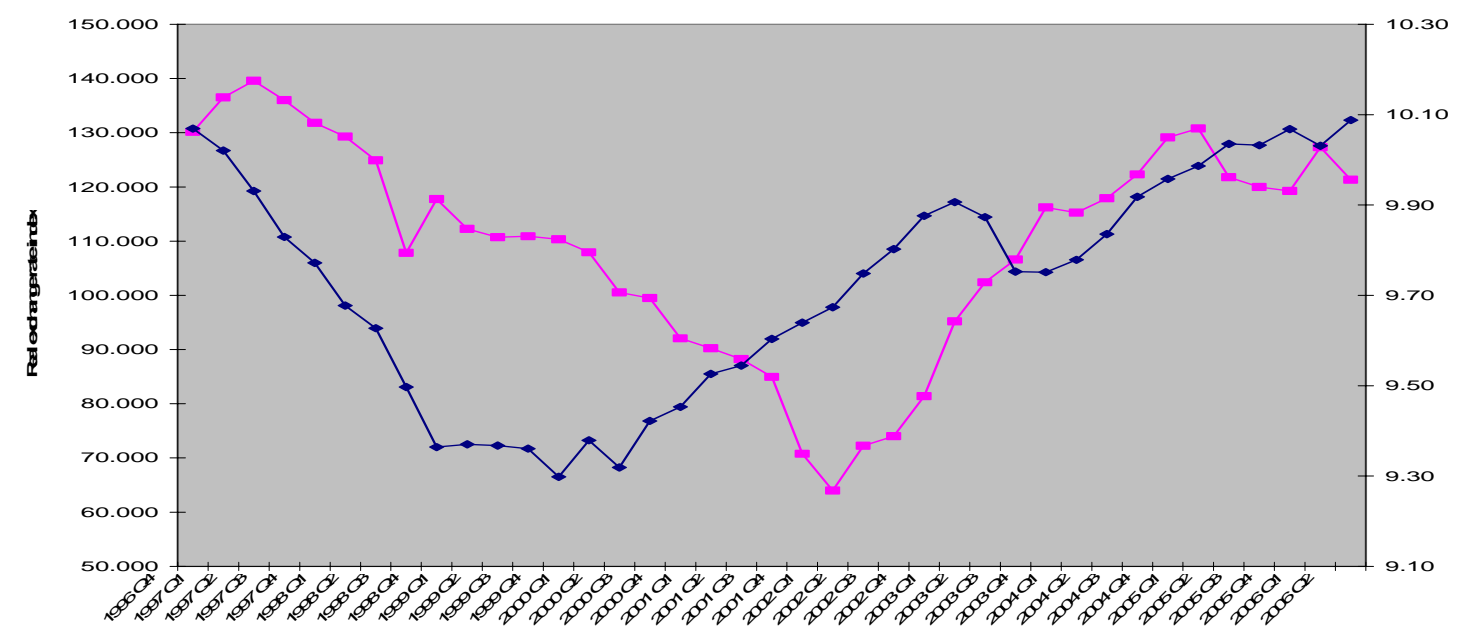

Figure 2: Real exchange rate and relative real GDP of SA to USA 


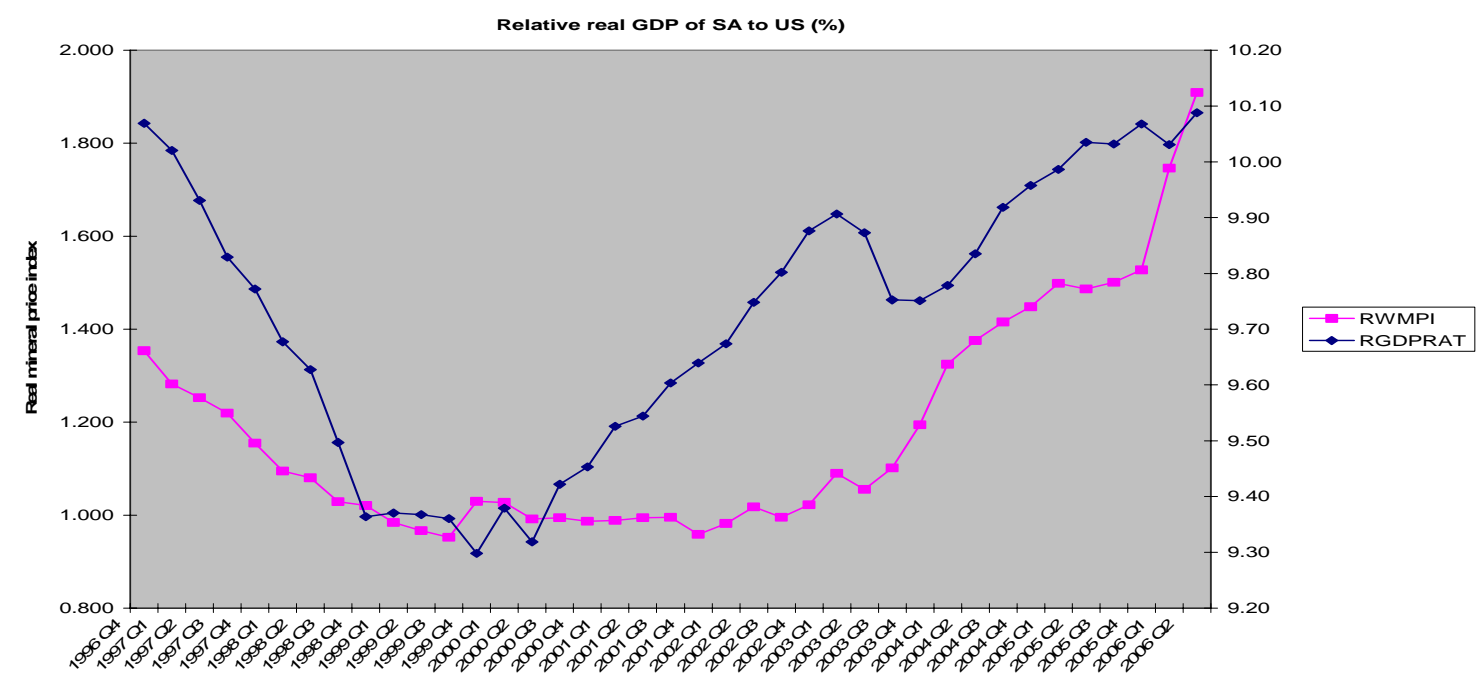

Figure 3: Real mineral price index and relative GDP

\section{Theoretical basis of model}

Here we focus on the determination of the real exchange rate, while recognizing that monetary factors are important. ${ }^{1}$ Our model of the real exchange rate divides its determinants into two categories, determinants of the long-run equilibrium exchange rate, and deviations of the current real exchange rate from its long-run equilibrium.

The long run equilibrium real exchange rate is given by a version of PPP:

$\bar{Q} \equiv \frac{E P^{*}}{P}, \quad$ or in log form: $\bar{q}=s+p^{*}-p$.

where $\mathrm{s} \equiv \log$ of the nominal spot exchange rate, in rand per dollars.

$\mathrm{p} \equiv \log$ of the South African price level (probably a PPI or the GDP deflator)

$\mathrm{p}^{*} \equiv \log$ of the foreign (here US) price level.

But we define the price indices at home and abroad as Cobb Douglas functions of traded goods TG and non-traded goods NTG:

$\mathrm{p}=\alpha \mathrm{p}_{\mathrm{NTGSA}}+(1-\alpha) \mathrm{p}_{\mathrm{TGSA}}$,

where $\alpha$ is the weight placed on NonTraded Goods in the basket .

For simplicity we assume the same weights in the foreign country.

$\mathrm{p}^{*}=\alpha \mathrm{p}_{\mathrm{NTGus}}+(1-\alpha) \mathrm{p}_{\mathrm{TGus}}$.

Combining (1), (2) and (3),

$$
\begin{gathered}
\bar{q}=s+p^{*}-p=s+\left[\alpha p_{N T G U S}+(1-\alpha) p_{T G U S}\right]-\left[\alpha p_{N T G S A}+(1-\alpha) p_{T G S A}\right] \\
=\left(s+p_{T G U S}-p_{T G S A}\right)+\alpha\left[\left(p_{N T G U S}-p_{T G U S}\right)-\left(p_{N T G S A}-p_{T G S A}\right)\right] .
\end{gathered}
$$

\footnotetext{
1 As Aron, Elbadawi and Kahn (2000).
} 
The first term can be interpreted as the terms of trade, the relative price of the traded goods produced in the foreign basket in terms of traded goods produced at home. We will proxy the terms of trade for South Africa by assuming that it depends on the real price of the basket of minerals that are its most important exports, $r m p$ in log form. The second term is the relative price of nontraded goods in terms of traded goods, abroad versus at home, with weight $\alpha$.. Real appreciation occurs when the relative price of nontraded goods rises more rapidly in the domestic country than in the former country. According to the well-known Balassa-Samuelson relationship, this in turn happens when the rate of growth in productivity and income per capita is higher at home than abroad (because the productivity growth tends to be concentrated in the traded goods sector, where prices are tied to world prices by arbitrage).

Thus $\left(p_{N T G U S}-p_{T G U S}\right)=\beta(\text { income per cap })_{U S}$ and $\left(p_{N T G S A}-p_{T G S A}\right)=\beta(\text { income per cap })_{S A}$. (One could easily add an appendix deriving these relationships.) Thus

$$
\bar{q}_{t}=\mu \mathrm{rmp}_{t}+\alpha \beta\left[(\text { income per cap })_{U s}-(\text { income per cap })_{S A}\right]_{t} .
$$

We will be including both variables, the real price of South African minerals and relative income per capita in the regression equation.

We turn now to the substantial short-term deviations, $(q-\bar{q})_{t}$, that real exchange rates experience relative to their long-run equilibrium value $(\bar{q})_{t}$. The idea is that such deviations arise routinely, but that they can be expected to correct themselves gradually over time, for example as sticky goods prices adjust. Assume that speculators form expectations according to the regressive specification, with the addition of a possible bubble component:

$$
\begin{aligned}
& E_{t} \Delta q=-\theta\left(q_{t}-\bar{q}_{t}\right)+\delta q_{t-1} \\
& E_{t} \Delta s=-\theta\left(q_{t}-\bar{q}_{t}\right)+E_{t} \Delta p-E \Delta p^{*}{ }_{t}+\delta q_{t-1}
\end{aligned}
$$

where $E_{t} \Delta q$ is defined to be the expectation formed at time $t$ of real depreciation over the coming period, and analogously for nominal depreciation and inflation, $\theta$ is the expected speed of regression toward the long run equilibrium, the speed with which deviations are thought to be corrected; and $\delta q_{t}$ is the possible bubble component. ${ }^{2}$ Assume also that uncovered interest parity holds, except for the country premium (default risk premium) that drives a wedge between South African interest rates and foreign interest rates, as reflected in the sovereign spread.

$$
E_{t} \Delta s=\left(i_{S A t}-i_{S A * t}\right)-(\text { risk spread } t)
$$

Now we combine equations (6) and (7)

\footnotetext{
${ }^{2}$ Regressive expectations is of course the formulation in the classic Dornbusch (1976) overshooting model, in which this functional form for expectations is shown to be rational for the right value of $\theta$ as a result of gradual adjustment of $p$. Frankel and Froot (1987) offered evidence from survey data that expectations at the one-year horizon do indeed encompass such regressive behavior. Rationales for the addition of the term $\delta q_{t}$ go back to the bubble literature of the late 1980s, e.g., the "dragging anchor" in Goodhart (1985) or the "overshooting of the overshooting equilibrium" in Frankel and Froot (1990). Some think that bandwagons or bubbles may have affected the rand at some points (e.g., the sharp fall in 2002). In any case, whatever the rationale, many authors, of which Mark (1995) is perhaps the best-known, have found empirically that an equation that includes the lagged exchange rate together with current fundamentals performs better than either fundamentals alone or the lagged rate alone (random walk), especially at longer horizons.
} 


$$
-\theta\left(q_{t}-\bar{q}_{t}\right)+E_{t} \Delta p-E \Delta p^{*} t+\delta q_{t-1}=\left(i_{S A t}-i_{S A * t}\right)-\left(\text { risk spread }_{t}\right),
$$

and solve for the current real exchange rate :

$$
\left.q_{t}=\bar{q}_{t}+\frac{\delta}{\theta} q_{t-1}-\left[\frac{1}{\theta}\left(i_{S A t}-i_{U S * t}\right)-\left(E_{t} \Delta p-E \Delta p_{t}^{*}\right)\right]+\frac{1}{\theta} \text { (risk spread }_{t}\right)
$$

Now bring this half of the model together with the other half, equation (5) :

$q_{t}=$

$\frac{\delta}{\theta} q_{t-1}+\mu r m p_{t}-\alpha \beta\left[(\text { income } p c)_{s A}-(\text { income } p c)_{u s}\right]_{t}-\left[\frac{1}{\theta}\left(r_{S A} t-r_{U S} t\right)\right]+\frac{1}{\theta}\left(\right.$ risk spread $\left._{t}\right)$

where we have defined the domestic and foreign real interest rates:

$r_{S A}=i_{S A t}-E_{t} \Delta p \quad$ and

$r_{U S t}=i_{U S t}-E_{t} \Delta p$.

Equation (9) represents our model.

\section{Estimated equation}

Our general equation to be estimated is:

Log Real value of Rand ${ }_{t}=$

$\alpha+\beta_{1} \log$ Real P Minerals $t_{t}+\beta_{2} \log \left(\right.$ SA GDP/foreign GDP) ${ }_{\mathrm{t}}$

$+\beta_{3} \log$ Rand value $\mathrm{t}_{\mathrm{t}-1}+\beta_{4}$ Real Interest Differential $_{\mathrm{t}}$

$+\beta_{5}$ Country Risk Spread $t+\beta_{6}$ trend $_{t}+u_{t}$.

- We have tried various versions of this equation: with the value of the rand defined bilateral against the dollar, or trade weighted.

- Real P Minerals $\mathrm{s}_{\mathrm{t}}$ is computed as a weighted average of the prices of the specific mineral products that South Africa produces and exports. It is intended to capture the terms of trade, and so is expressed in real form by deflating by the foreign (e.g., US) price level.

- (SA GDP/foreign GDP) ${ }_{t}$ often appears in nominal exchange rate equations as an important determinant of the demand for money (domestic relative to foreign). We are perhaps on firm ground theoretically, when seeking to explain the real exchange rate, to invoke a Balassa-Samuelson effect, in which case real output per capita would be the more relevant variable. In any case, it is only possible to include the GDP variable when we are working with quarterly data; we are forced to drop it when working with monthly data, unless we interpolate.

- Log Rand Value $t_{t-1}$ is entered to capture the idea of a dragging anchor or momentum elements. 
- The remaining variables capture rates of return. It is not enough simply to add interest rates as a rate of return, and hope for a positive coefficient, because nominal high interest rates in developing countries usually reflect expected inflation, default risk, and devaluation risk.

o Real interest differential (nominal interest rate on rand government bonds, minus expected inflation, minus the same for abroad) should have a positive effect on the perceived rate of return to holding rand assets and therefore on the value of the rand. In the past we have used the one-year lag in the inflation rate as a simple way of capturing expected inflation. But we now have better forward-looking measures of expected inflation, in the form of professional forecasts in South Africa and the US : We are now using measures of ex ante expectations: the Federal Reserve Bank of Philadelphia Survey of Professional Forecasters in the case of US inflation ${ }^{3}$ and formal Bureau of Economic Research forecasts in the case of South Africa.

o A country risk premium is included to control for risk of default, or risk of future imposition of capital controls, when looking for a positive coefficient on the real interest differential. After all, a high interest differential does not attract investors to the extent that it merely reflects a correspondingly high fear of default. The preferred measure of the country risk premium is the spread between the interest rate at which South Africa borrows when borrowing in dollars (not rand, because we want to separate out currency risk) and a foreign dollar interest rate of the same maturity. We have now obtained data from the Treasury on the sovereign spread for borrowing by the South African government in dollars. ${ }^{4}$ The series is illustrated in Figure 5. One can see an impressive downward trend in the perceived risk of South African debt since 2002, to well below 100 basis points in early 2006, in tandem with some upgrades of South African debt by rating agencies. ${ }^{5}$

\footnotetext{
${ }^{3}$ Ang, Bekaert and Wei (2005) provide support for using such survey data.

${ }^{4}$ In earlier results we used a proxy: the spread between the corporate rand interest rate and the government rand rate, under the theory that when default risk raises the South African government interest rates, it raises the corporate interest rate proportionately more. But the sovereign spread is a much better measure of country risk.

${ }^{5}$ MacDonald and Ricci (2003) have a rather similar list of variables in their equation. Perhaps our main improvements relative to their set are the expected return variables.
} 
Figure 5: Spreads on South African Dollar Debt

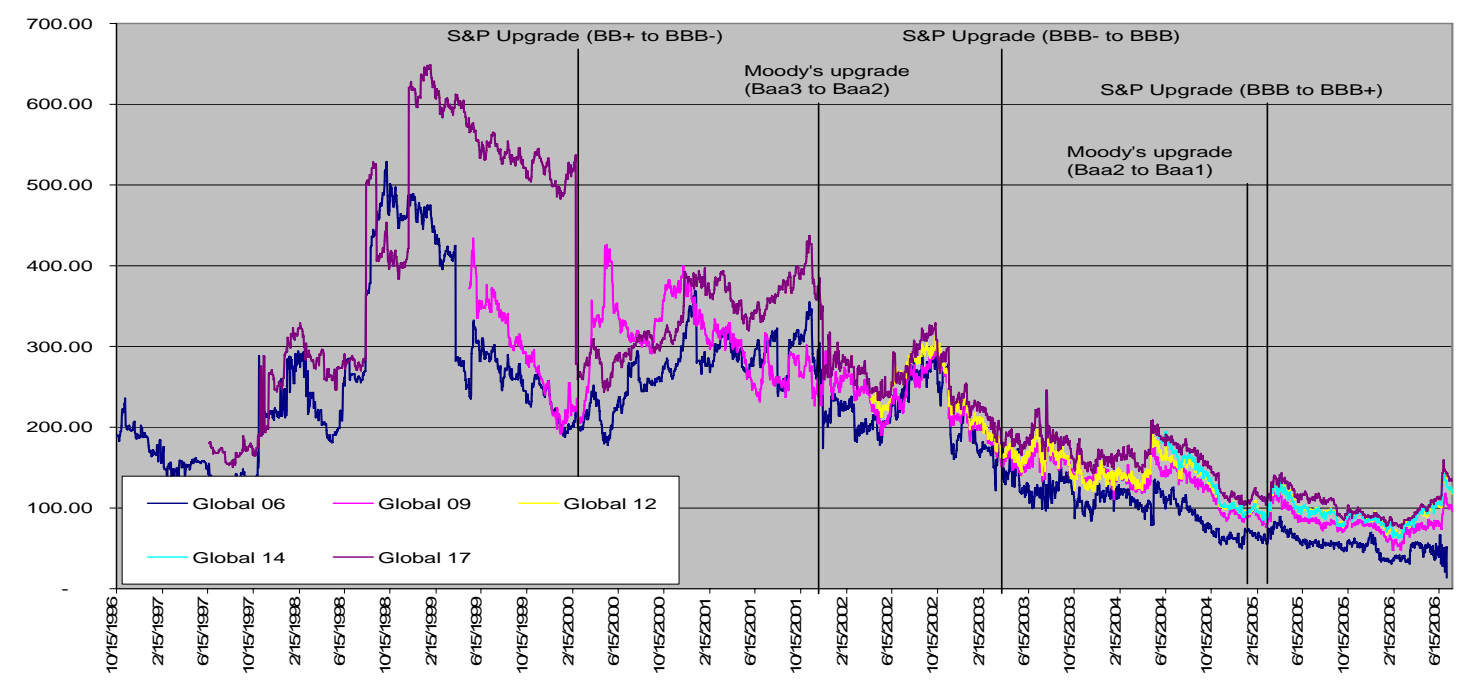

Sovereign spreads have come down across emerging markets, of course, but international investors appear to have far more confidence in South Africa than in others, as Figure 6 shows.

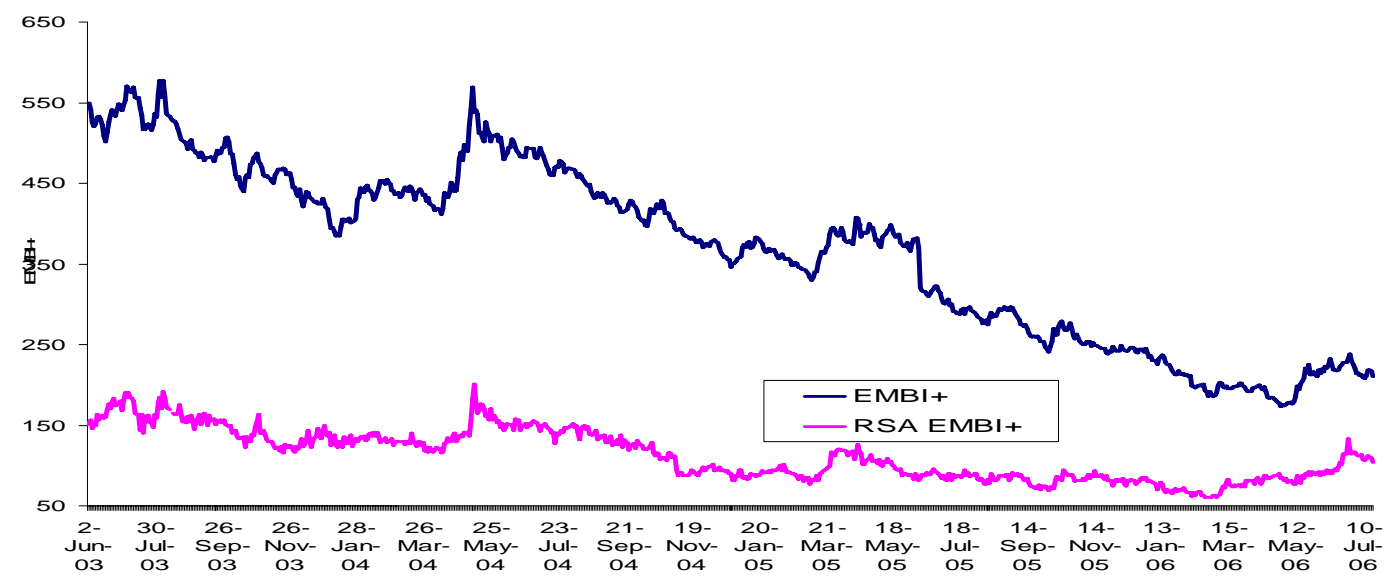

Figure 6: South African spread compared to aggregate of emerging market bonds.

Further details on data sources and how these variables were computed are given in the appendix. 


\section{Results}

The regression results for the nominal and real exchange rate are highly varied. But the real commodity price index does appear generally to have the hypothesized positive sign. The lagged endogenous variable shows up highly significant, suggesting either a momentum/dragging anchor phenomenon, or else the omission of (serially correlated) determinants. The Breusch-Godfrey LM Test suggests that the use of the lagged endogenous variable does not leave in its wake much grounds for concern about serial correlation.

Income per capita appears with the wrong sign when the regression is run using the real exchange rate for the entire sample period, and significantly so. (The same is true when we include total income rather than per capita, as in old models based on the demand for money.) If we include income per capita (or income) without the real mineral price index, then it appears statistically significant and of the expected sign. Evidently, and not surprisingly, real income is highly collinear with mineral prices. But mineral prices knock out real income when they compete side-by-side. Perhaps when we control for the exogenous supply-side influence of the world mineral prices, the remaining variation in income captures endogenous response to fluctuations in demand, which have negative effects on the trade balance and through this route on the value of the currency. In any case, the results are a decisive rejection of the importance of the Balassa-Samuelson effect in this context. If one is convinced that this conclusion is right, then one should omit the per capita differential from the equation.

The results for the rate of return variables are important. For many emerging markets, it is hard to find a positive effect of the interest differential on demand for the currency, presumably because nominal interest rates in practice signal rears of inflation, depreciation, and default, rather than high expected returns. Results that properly use the dollar spread on South African borrowing to measure the risk premium show a highly significant negative effect on the value of the rand, as hypothesized. The real interest differential has the hypothesized positive effect.

The 1990s saw important structural changes in South Africa, with the transition to democracy, ${ }^{6}$ the end of foreign sanctions, and the removal of most capital controls in March 1995. The capital account liberalization is probably the most relevant of these changes for the exchange rate equation. There had been a dual exchange rate system that had separated the financial market for rand from the trade account, charging customers a higher rand price for foreign exchange if the purpose was to acquire assets abroad. ${ }^{7}$ These structural changes provide an argument for starting the sample in 1996. Another reason is that the sovereign spread data are only available since 1996 anyway. But we have also continued to run some regressions over the longer sample period, in order to maximize the number of observations. On the theory that the degree of capital mobility increased in March 1995, we allowed for the possibility of a shift in the coefficient on the real interest differential, but the variable (the differential interacted with a dummy that takes the value of 1 post-March 1995) was not statistically significant, or even greater than zero. We also tried estimating the post-1995 sample by itself, but the results were

\footnotetext{
${ }^{6}$ Aron and Elbadawi(1999) describe a sequence of capital inflows into South Africa after its democractic elections in 1994, followed by a speculative attack in 1996.

${ }^{7}$ See Farrell and Todani (2004) and Patrick Bond (1999).
} 
unsatisfactory, perhaps because of the smaller number of observations. But extending the sample back to the 1980s unfortunately means losing the country risk variable, since th sovereign spread data only start in 1996.

\section{(i) RER based on CPI}

\section{Dependent Variable: LOG(RERICPI)}

Method: Least Squares

Sample(adjusted): 1984:2 2006:2

Included observations: 89 after adjusting endpoints

\begin{tabular}{|c|c|c|c|c|}
\hline Variable & Coefficient & Std. Error & t-Statistic & Prob. \\
\hline LOG(RERICPI(-1)) & 0.817 & 0.043 & 18.891 & 0.0000 \\
\hline LOG(RWMPI) & 0.234 & 0.066 & 3.573 & 0.0006 \\
\hline RGBRDIF & 0.021 & 0.005 & 3.943 & 0.0002 \\
\hline DUMMYCAPLIB & -0.037 & 0.024 & -1.559 & 0.1229 \\
\hline DUMMYRGBRDIF & -0.011 & 0.006 & -1.835 & 0.0701 \\
\hline C & 0.815 & 0.203 & 4.022 & 0.0001 \\
\hline R-squared & 0.918 & \multicolumn{2}{|c|}{$\overline{\text { Mean dependent var }}$} & 834 \\
\hline Adjusted R-squared & 0.912 & \multicolumn{2}{|c|}{ S.D. dependent var } & 0.216 \\
\hline S.E. of regression & 0.064 & \multicolumn{2}{|c|}{ F-statistic } & 184.093 \\
\hline Sum squared resid & 0.339 & \multicolumn{2}{|c|}{ Prob(F-statistic) } & 0.000 \\
\hline Log likelihood & 121.609 & \multicolumn{2}{|c|}{ Durbin-Watson stat } & 1.766 \\
\hline
\end{tabular}

\section{Breusch-Godfrey Serial Correlation LM Test:}

\begin{tabular}{lll} 
F-statistic & 0.561 & $\begin{array}{l}\text { Probability } \\
\text { Obs*R-squared }\end{array}=$ \\
\hline
\end{tabular}

\section{(ii) RER based on PPI}

\section{Dependent Variable: LOG(RERIPPI)}

Method: Least Squares

Sample(adjusted): 1984:2 2006:2

Included observations: 89 after adjusting endpoints

\begin{tabular}{|c|c|c|c|c|}
\hline Variable & Coefficient & Std. Error & t-Statistic & Prob. \\
\hline LOG(RERIPPI(-1)) & 0.808 & 0.048 & 16.823 & 0.0000 \\
\hline LOG(RWMPI) & 0.186 & 0.062 & 2.990 & 0.0037 \\
\hline RGBRDIF & 0.019 & 0.005 & 3.541 & 0.0007 \\
\hline DUMMYCAPLIB & -0.031 & 0.022 & -1.378 & 0.1719 \\
\hline DUMMYRGBRDIF & -0.012 & 0.006 & -2.002 & 0.0486 \\
\hline $\mathrm{C}$ & 0.874 & 0.226 & 3.874 & 0.0002 \\
\hline R-squared & 0.896 & \multicolumn{2}{|c|}{ Mean dependent var } & 815 \\
\hline Adjusted R-squared & 0.890 & \multicolumn{2}{|c|}{ S.D. dependent var } & 185 \\
\hline S.E. of regression & 0.061 & \multicolumn{2}{|c|}{ Sum squared resid } & 311 \\
\hline Log likelihood & 125.460 & \multicolumn{2}{|l|}{ F-statistic } & 43.441 \\
\hline Durbin-Watson stat & 1.828 & \multicolumn{2}{|c|}{ Prob(F-statistic) } & 000 \\
\hline
\end{tabular}

Breusch-Godfrey Serial Correlation LM Test:

\begin{tabular}{llll} 
F-statistic & 0.425 & Probability & 0.655 \\
Obs*R-squared & $=$ & 0.925 & Probability \\
\hline \hline
\end{tabular}




\section{(iii) RER based on GDP Deflator}

Dependent Variable: LOG(RERIGDPDEF)

Method: Least Squares

Sample(adjusted): 1984:2 2006:2

Included observations: 89 after adjusting endpoints

\begin{tabular}{|c|c|c|c|c|}
\hline Variable & Coefficient & Std. Error & t-Statistic & Prob. \\
\hline LOG(RERIGDPDEF(-1)) & 0.839 & 0.043 & 19.269 & 0.0000 \\
\hline LOG(RWMPI) & 0.181 & 0.062 & 2.945 & 0.0042 \\
\hline RGBRDIF & 0.022 & 0.006 & 3.932 & 0.0002 \\
\hline DUMMYCAPLIB & 0.007 & 0.022 & 0.318 & 0.7511 \\
\hline DUMMYRGBRDIF & -0.018 & 0.006 & -2.783 & 0.0067 \\
\hline $\mathrm{C}$ & 0.703 & $0.199=$ & 3.535 & 0.0007 \\
\hline R-squared & 0.894 & $\overline{\text { Mean depen }}$ & lent var & 4.727 \\
\hline Adjusted R-squared & 0.888 & S.D. depend & ent var & 0.187 \\
\hline S.E. of regression & 0.063 & Sum squared $\mathrm{r} \epsilon$ & & 0.327 \\
\hline Log likelihood & 123.25 & F-statistic & & 139.98 \\
\hline Durbin-Watson stat & 1.7532 & Prob(F-statis & & 0.000 \\
\hline
\end{tabular}

Breusch-Godfrey Serial Correlation LM Test:

\begin{tabular}{llll} 
F-statistic & 0.6776 & Probability & 0.5107 \\
Obs ${ }^{*}$-squared & 1.4645 & Probability & 0.4808 \\
\hline
\end{tabular}

\section{How does the value of the rand compare to the equation's prediction?}

Figures 7, 8, and 9 plot the actual real value of the rand (using different price indices) against the value predicted by the equation. In general the fit is remarkably close. It is natural to suspect that this may be largely due to the lagged endogenous variable, in which case the equation would not be of much use in forecasting.

Figure 10 adds a "dynamic simulation," that is, a projected path for the last three years of the sample based only on fundamentals. The value of QIII, 2003, is the last one to use the actual exchange rate for the lagged endogenous variable. From then on, the lagged prediction of the equation itself is used as the lagged endogenous variable, rather than the actual. Nevertheless, based on fundamentals such as a rising price of minerals, the projection predicts as strong a real appreciation of the rand through mid-2006 as did the fitted values of the regression.

Thus the equation does not supply evidence in favor of the proposition that the rand was undervalued (as of late 2006) when judged by its own past relationship to economic fundamentals. But then efficiency in the financial market sense is not the same thing as efficiency in the sense of correct signals for the allocation of resources in the real economy. ${ }^{8}$ The speculative inflows during the recent boom in commodities and emerging markets may be "par for the course;" but this is not inconsistent with the proposition that crowding out of non-commodity tradables could have negative consequences in the long run.

\footnotetext{
${ }^{8}$ For recent theoretical illustration: Devereux and Engel (2006) or Caballero (2007).
} 


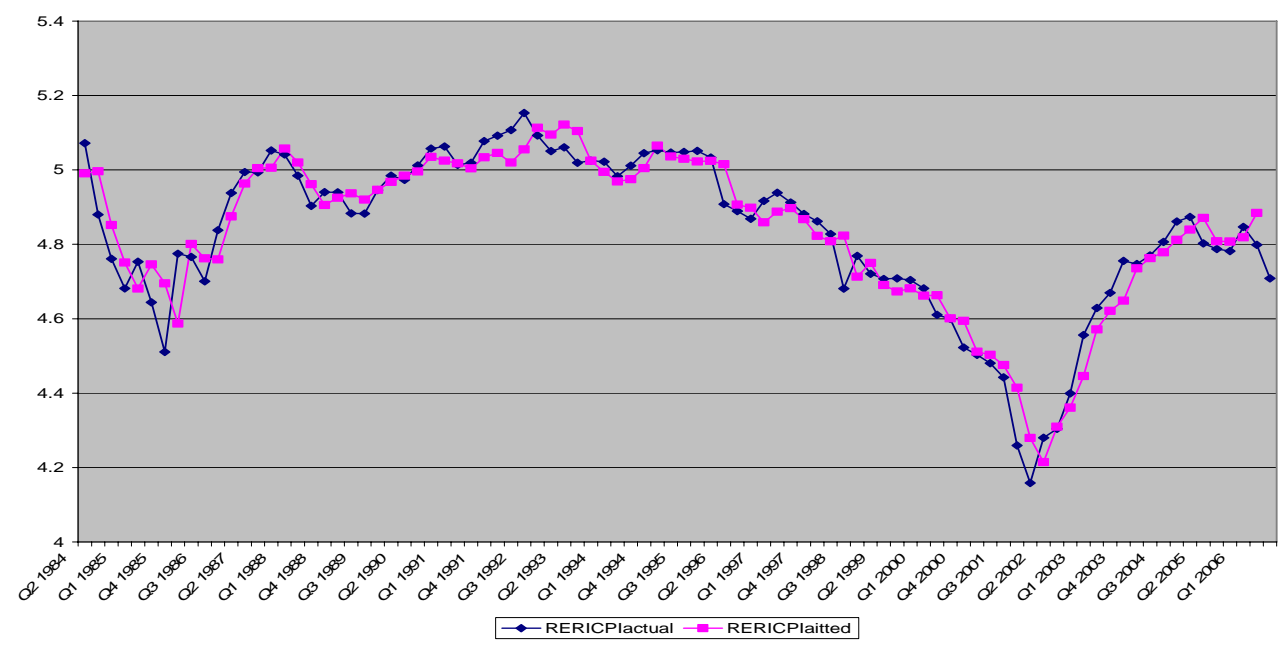

Fig. 7 Actual vs Fitted Real Value of the Rand, based on the CPI (1984:II-2006:II)

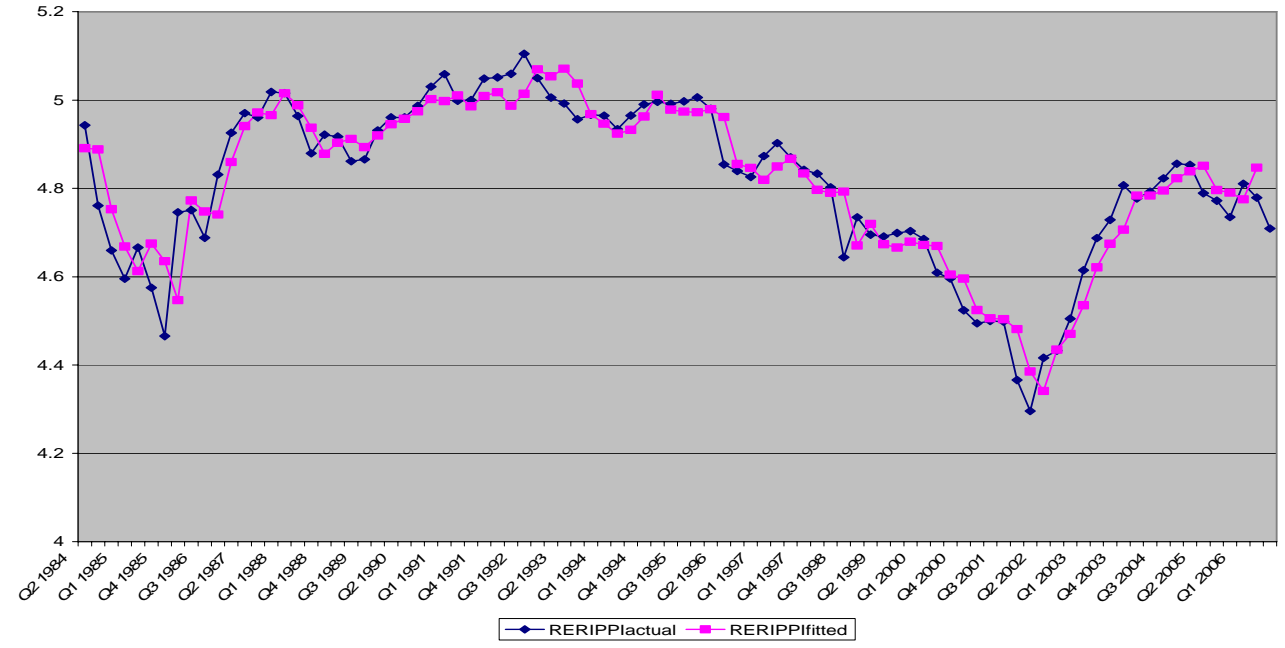

Fig. 8 Actual vs Fitted Real Value of the Rand, based on PPI (1984:II-2006:II) 


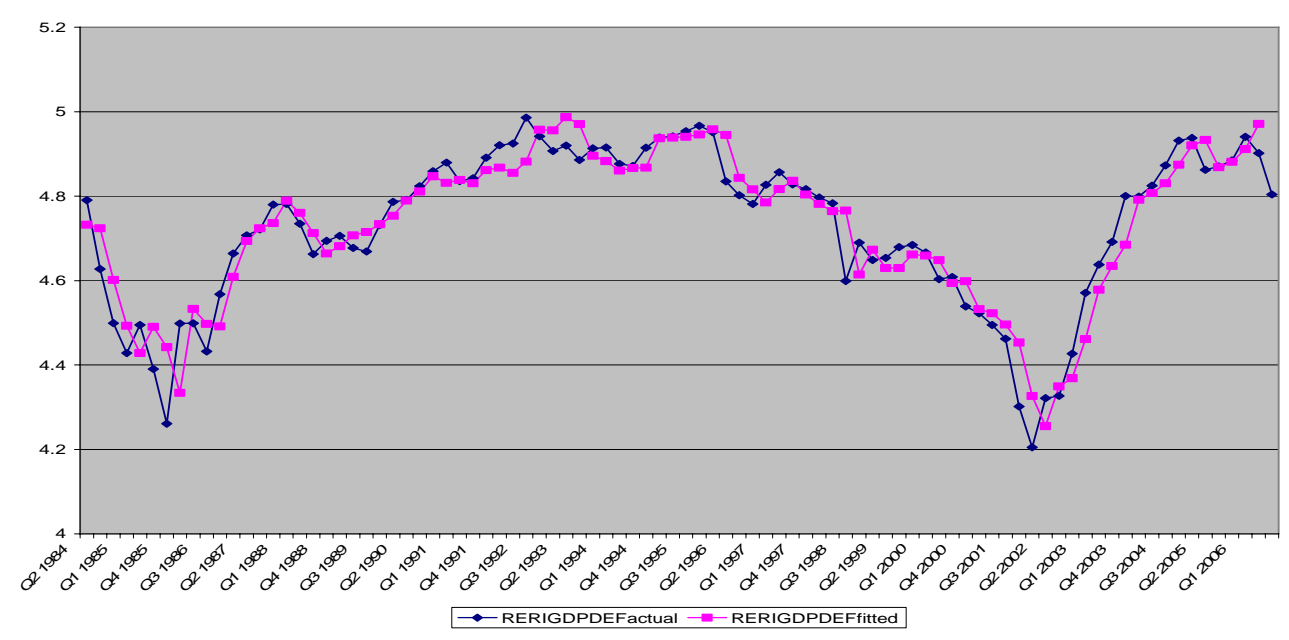

Fig. 9 Actual vs Fitted Real Value of the Rand, based on GDP Deflator (1984:II-2006:II)

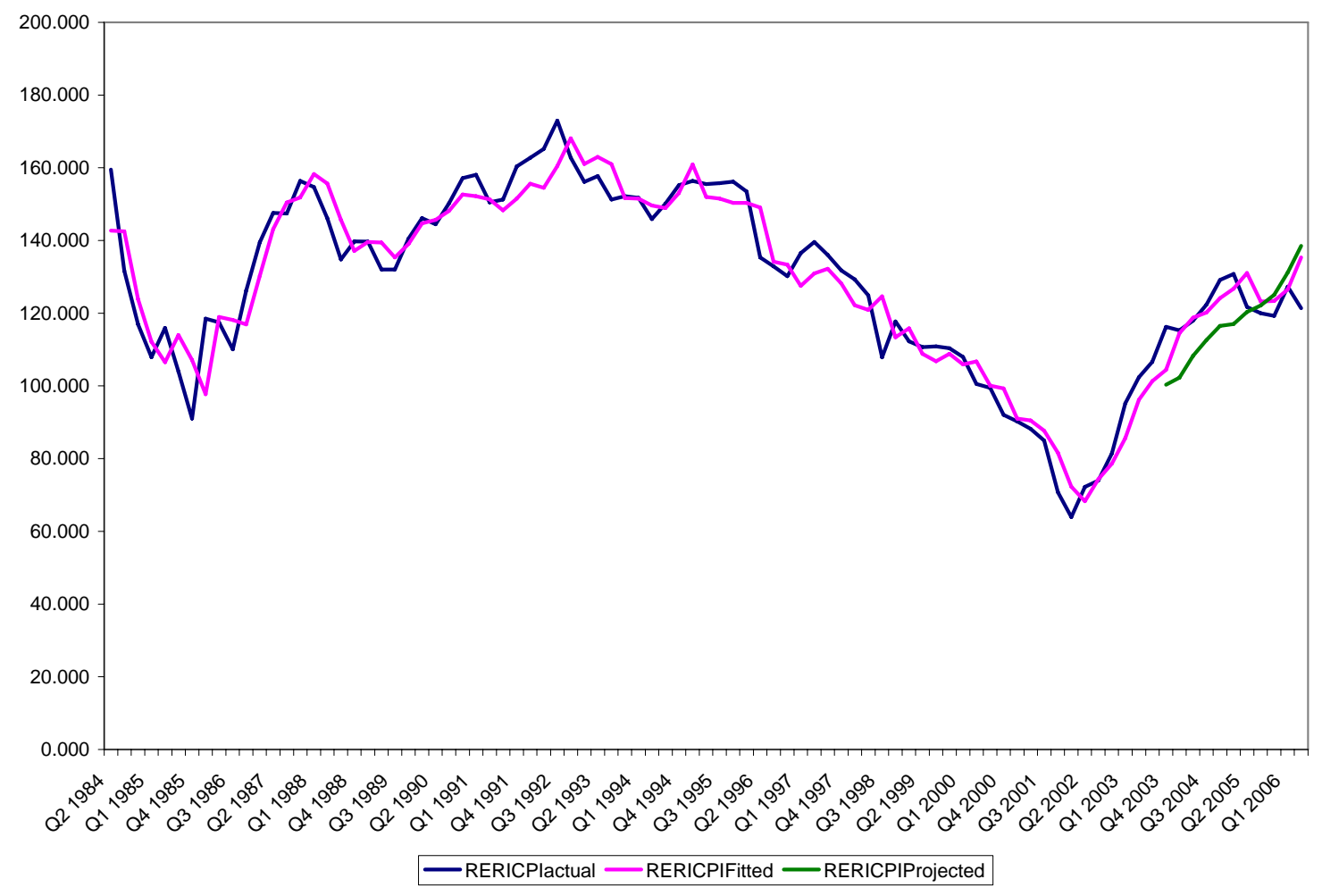

Fig.10: Actual vs. Fitted vs. Projected Real Value of Rand, based on CPI (1984:II-2006:II) 


\section{$\underline{\text { References }}$}

Ang, A., G. Bekaert and M. Wei, 2005, "Do Macro Variables, Asset Markets or Surveys Forecast Inflation Better?"

Aron, Janine, and Ibrahim Elbadawi, 1999, "Reflections on the South African rand crisis of 1996 and policy consequences," Centre for the Study of African Economies Working Paper Series No. 97, Sept. 20.

Aron, Janine, Ibrahim Elbadawi, and Brian Kahn, 2000, "Real and Monetary Determinants of the Real Exchange Rate in South Africa," in Development Issues in South Africa, edited by Ibrahim Elbadawi and Trudi Hartzenberg (MacMillan: London).

Bond, Patrick, 1999, "A Case for Capital Controls," University of the Witwatersrand, Graduate School of Public and Development Management, December.

Caballero, Ricardo, 2007, "Persistent Appreciations and Overshooting: A Normative Analysis," MIT.

Devereux, Michael, and Charles Engel, 2006, "Expectations and Exchange Rate Policy,” NBER Working Paper No. 12213, May.

Dornbusch, Rudiger, 1976, “Expectations and Exchange Rate Dynamics," Journal of Political Economy 84, no. 6, December.

Farrell, G.N., and K.R. Todani, 2004, "Capital Flows, Exchange Control Regulations and Exchange Rate Poliyc: The South African Experience," OECD Seminar, Bond Exchange of South Africa, March.

Frankel, Jeffrey and Kenneth Froot, 1987, "Using Survey Data to Test Standard Propositions Regarding Exchange Rate Expectations," American Economic Review 77, 1 (March): 133-53. Reprinted as Chapter 13 in Frankel, On Exchange Rates.

Frankel, Jeffrey and Kenneth Froot, 1990, "Chartists, Fundamentalists, and the Demand for Dollars," in Anthony Courakis and Mark Taylor, eds., Private Behavior and Government Policy in Interdependent Economies. Oxford: Clarendon Press.

Goodhart, Charles, 1988, "The Foreign Exchange Market: A Random Walk with a Dragging Anchor," Economica 55, 437-60.

MacDonald, Ronald, and Luca Ricci, 2003, "Estimation of the Equilibrium Real Exchange Rate for South Africa," IMF Working Paper /03/44.

Mark, Nelson, 1994, "Exchange Rates and Fundamentals: Evidence on Long-Horizon Predictability," American Economic Review. 


\section{Data Notes}

Nominal Exchange Rate (NER): is the nominal foreign exchange value of South Africa's currency expressed in USD per South African Rand.

Real Bilateral Exchange Rate Index: is the nominal exchange rate multiplied by the ratio of South African price index to US price index, expressed in index form with base year 2000. Three real exchange rate indices are constructed based on three different price indices. These are real exchange rate index based on CPI (RERICPI), real exchange rate based on PPI (RERIPPI) and real exchange rate based on GDP deflator $(R E R I G D P D E F)$. The three series are plotted and given below for comparison.

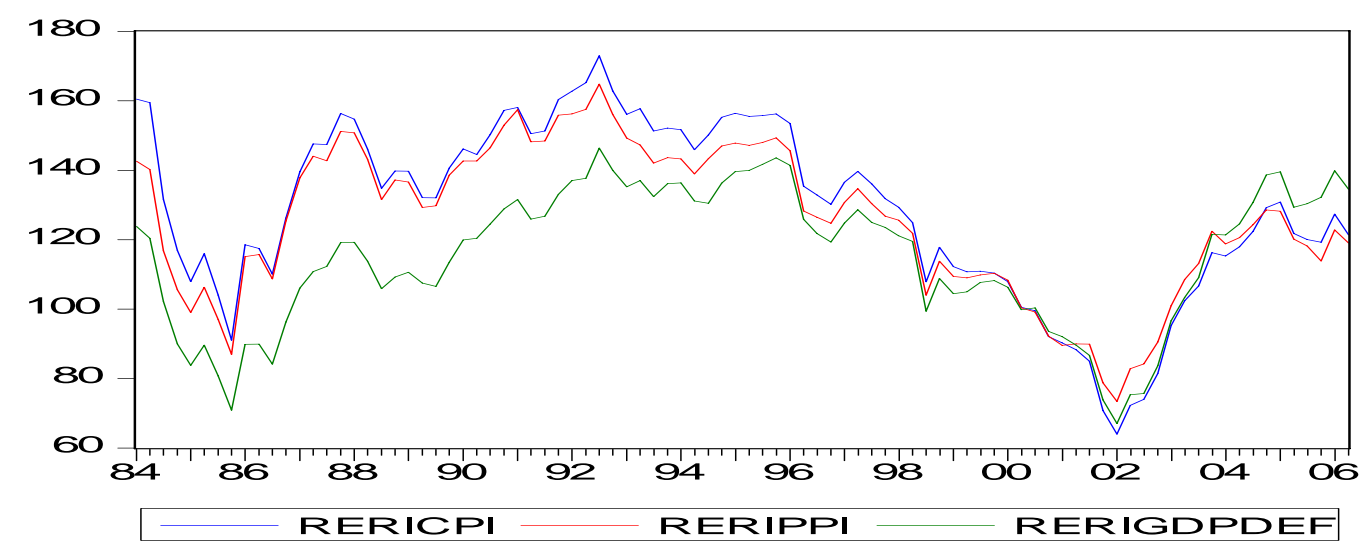

\section{Real Mineral and Metal Price Index:}

The nominal weighted mineral and metal price index (WMPI) is the weighted price index of South African major mineral and metal export commodities. Weights are derived from the commodity's export share in the value of total exports of South Africa. While efforts are made to include all major commodities, some of them, such as diamond, are not included due to lack of international price index. The commodities included and their weights are given below:

Table: South African Major Export Commodities

\begin{tabular}{|l|r|r|}
\hline Commodity Group & Actual \% share & $\begin{array}{l}\text { Adjusted \% } \\
\text { share }\end{array}$ \\
\hline Gold and platinum & 17.54 & 56.22 \\
Iron ores & 2.78 & 8.90 \\
Coal & 5.69 & 18.23 \\
Petroleum Oil & 2.81 & 9.01 \\
Aluminum & 2.38 & 7.64 \\
\hline Total & $\mathbf{3 1 . 1 9}$ & $\mathbf{1 0 0 . 0 0}$ \\
\hline
\end{tabular}

Source: Compiled from data from South African Trade and Industry Department

The real weighted mineral and metal price index (RWMPI) is the WMPI divided by the consumer price index of the US.

Expected Inflation Rates: The source of US's expected inflation rate is the Federal Reserve Bank of Philadelphia. The South Africa expected inflation rate is the inflation forecasts from the macro model of South Africa's Bureau of Economic Research, provided by Professor Ben W Smit. 
Real Interest Rate Differentials (RGBRDIF): The long term government bond yields of the US and South Africa are obtained from the IFS, IMF database. Then respective expected inflations are subtracted from nominal long term bond yields to get the real interest rates. The real interest rate differential is then the difference between SA's real government bond rate and US's real government bond rate.

\section{GDP Ratios}

Real and nominal GDPs are collected for South Africa and the US from IFS, IMF, and the following ratio are calculated:

(i) Real GDP ratio between S. Africa and the US (RGDPrat)

(ii) Nominal GDP ratio between S. Africa and the US (NGDPrat)

(iii) Real per capita GDP ratio between S. Africa and the US (PERGDPrat)

Quarterly per capita GDPs are calculated using quarterly real GDPs and extrapolated quarterly population. The annual mid-year population estimates, obtained from IFS, were decomposed to quarterly using the following formula:

Year t Q1 pop $=3 / 8 *($ year t-1 pop $)+5 / 8 *($ year t pop $)$

Q2 pop $=1 / 8 *($ year t 1 pop $)+7 / 8 *($ year t pop $)$

$\mathrm{Q} 3$ pop $=7 / 8 *($ year $\mathrm{t}$ pop $)+1 / 8 *($ year $\mathrm{t}+1$ pop $)$

$\mathrm{Q} 4$ pop $=5 / 8 *($ year $\mathrm{t}$ pop $)+3 / 8 *($ year $\mathrm{t}+1$ pop $)$

The following Figures show how the generated quarterly per capita GDP series tracked the annual figures obtained from the World Development Indicators, World Bank.

Figure: Annual (left) and Quarterly (Right) series of per capita GDP: South Africa

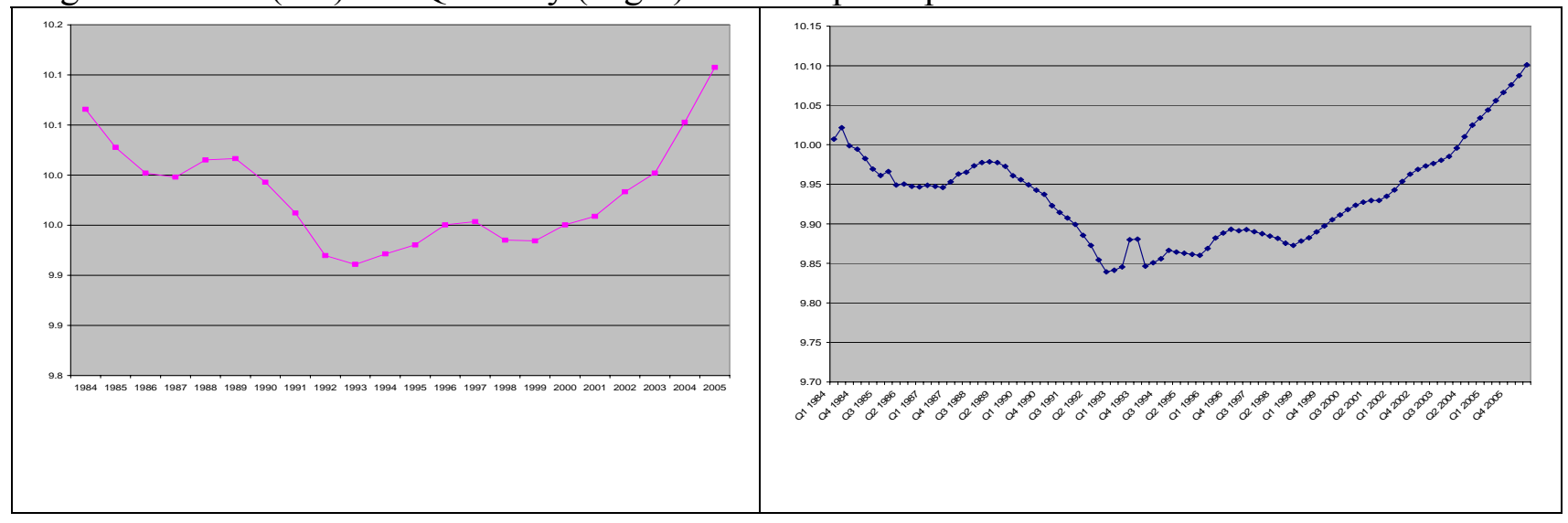


Figure: Annual (left) and Quarterly (Right) series of per capita GDP: USA

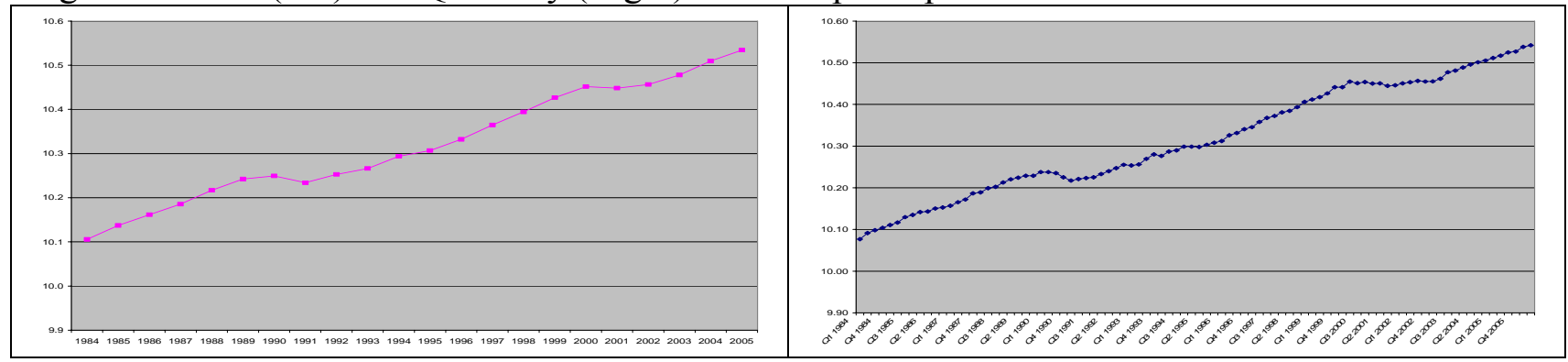

Dummy Capital Market Liberalization (DUMMYCAPLIB): A dummy for capital market liberalization, which has a value of one since the second quarter of 1995, when South African capital market was liberalized, and zero elsewhere.

DUMMYRGBRDIF comes from DUMMYCAPLIB interacted with the real interest rate differential 